\title{
STATUS PRAWNY I PRAKTYKA FUNKCJONOWANIA PODKOMISJI W SEJMIE RP
}

\section{LEGAL STATUS AND PRACTICE OF THE FUNCTIONING OF SUBCOMMITTEES IN THE SEJM OF THE REPUBLIC OF POLAND}

The article provides an analysis of the Standing Orders of the Sejm of the Republic of Poland concerning the functioning of subcommittees against the parliamentary practice of the seven terms of the Sejm (1991-2015). Herein, subcommittees are classified based on the subject matter of their activity and tasks. The most important legal problems concerning subcommittees' activities, resulting from parliamentary practice, are also presented, such as establishing subcommittees, electing chairpersons, the course of subcommittee sittings and dissolving subcommittees.

Słowa kluczowe: podkomisja, komisja, Sejm, parlament, proces ustawodawczy

Key words: subcommittee, committee, Sejm, parliament, legislative process

* Dr Mariusz A. Kamiński, Akademia Sztuki Wojennej, Wydział Bezpieczeństwa Narodowego, Instytut Prawa i Administracji Obronnej; m.a.kaminski@akademia.mil.pl

\section{UWAGI WSTĘPNE}

Dodkomisje sejmowe są trwałym i istotnym elementem polskiego systemu parlamentarnego. Odgrywają ważną rolę zarówno w procesie ustawodawczym, jak też w wykonywaniu przez Sejm jego funkcji kontrolnej. Zakres ich prac bywa też dużo szerszy i nie ogranicza się jedynie do szczegółowego rozpatrywania projektów ustaw i uchwał.

Celem niniejszej publikacji jest przedstawienie analizy przepisów regulaminu Sejmu Rzeczypospolitej Polskiej [dalej też: rS] ${ }^{1}$, regulujących działanie podkomisji, oraz ukazanie praktyki ich funkcjonowania w trakcie siedmiu kadencji Sejmu (1991-2015). W artykule zaprezentowano również wyniki badań własnych autora, przeprowadzonych nad sprawozdaniami komisji sejmowych od I do VII kadencji (łącznie 178 dokumentów) ${ }^{2}$. Analiza umożliwiła klasyfikację podkomisji pod względem tematycznym i zakresu zadań, jakie wykonują. Takie ujęcie zagadnienia pozwoliło na uchwycenie szeregu problemów dotyczących prawnych aspektów działalności podkomisji, począwszy od ich powołania i ustalenia składu osobowego, przez wybór przewodniczącego i prezydium oraz przebieg posiedzenia, aż po zakończenie prac i likwidację podkomisji.

\footnotetext{
${ }^{1}$ Uchwała Sejmu RP z dnia 30 lipca 1992 r. — Regulamin Sejmu Rzeczypospolitej Polskiej, M.P. z 1992 r. nr 26, poz. 185 , ze zm.

2 Vide M.A. Kamiński, „Spis sprawozdań komisji sejmowych wykorzystanych w badaniach własnych nad praktyką działania podkomisji w Sejmie RP”, <www.researchgate.net/>, dostęp 30 XI 2017.
} 


\section{POWOLANIE PODKOMISJI}

W regulaminie Sejmu wyróżnia się trzy rodzaje podkomisji: nadzwyczajne, stałe oraz podkomisje stałe przy komisjach nadzwyczajnych do rozpatrzenia kodeksów. Ich działalność jest ściśle związana z pracą oraz zakresem kompetencji poszczególnych komisji sejmowych. Ponieważ podkomisje są wewnętrznymi organami pomocniczymi komisji, to podstawy prawne ich działalności stanowią właściwie wyłącznie materię regulaminowa ${ }^{3}$. Niestety w regulaminie Sejmu nie zawarto całościowego i kompleksowego unormowania działalności podkomisji.

Przepisy dotyczące ich powołania rozmieszczono w trzech różnych rozdziałach regulaminu:

— w rozdziale zatytułowanym „Postępowanie z projektami ustaw i uchwał” zawarto przepis, na podstawie którego powołuje się podkomisje do szczegółowego rozpatrzenia projektu ustawy bądź uchwały (art. 41);

— w rozdziale „Postępowanie z projektami kodeksów” uregulowano kwestie związane z powołaniem podkomisji stałych przy komisjach nadzwyczajnych do rozpatrzenia projektów kodeksów (art. 91);

— natomiast w rozdziale „Posiedzenia komisji sejmowych” umieszczono przepisy dotyczące podkomisji stałych oraz innych podkomisji nadzwyczajnych (art. 165).

Zgodnie z art. 165 ust. 1 rS, ,komisje mogą ze swojego składu powoływać podkomisje, określając ich skład oraz zakres działania; powołanie podkomisji stałej wymaga zgody Prezydium Sejmu". Na podstawie tego przepisu komisje sejmowe moga utworzyć zarówno tzw. podkomisje nadzwyczajne, jak i podkomisje stałe, ich zakres działania bardzo często jest jednak zbliżony. Różnica sprowadza się głównie do czasu, na jaki podkomisja zostaje powołana, oraz obowiązku uzyskania zgody Prezydium Sejmu (w przypadku podkomisji stałej). Należy podkreślić, że nazwa ,podkomisja nadzwyczajna” została wypracowana w praktyce parlamentarnej, ponieważ w regulaminie Sejmu nie użyto takiej nazwy ${ }^{4}$.

Podkomisja stała wykonuje swoje zadania permanentnie i działa zazwyczaj od chwili jej utworzenia aż do zakończenia kadencji ${ }^{5}$. Przeważnie tematami prac podkomisji stałych są konkretne bloki problemowe, którymi zajmują się komisje, np. w przy-

3 Wyjątek stanowi przepis art. 26 ust. 1 pkt 3 ustawy z dnia 9 maja 1996 r. o wykonywaniu mandatu posła i senatora (Dz.U. z 2016 r. poz. 1510; dalej: u.w.m.p.s.), w którym przewidziano 10-procentowy dodatek do uposażenia dla przewodniczącego podkomisji stałej.

4 W praktyce parlamentarnej właśnie tak nazywane są podkomisje powoływane do szczegółowego rozpatrzenia danego projektu; vide lista podkomisji na stronie internetowej Sejmu RP <www.sejm.pl>, dostęp 30 XI 2017.

5 Jak podkreśla M. Zubik, „Przez podkomisję stałą rozumie się taka podkomisję, której zadanie określone są rodzajowo (a nie w odniesieniu do konkretnej sprawy) i która funkcjonuje w przedziale czasowym pokrywającym się niekiedy z kadencją izby (a nie na czas konieczny do rozpatrzenia sprawy)"; vide M. Zubik, Organizacja wewnętrzna Sejmu Rzeczypospolitej Polskiej, Warszawa 2003, s. 312. H. Pajdała wskazuje, że „można zatem domniemywać, że podkomisje stałe, powoływane w tym trybie, odnoszą się do prac problemowych o ściśle określonym obszarze"; vide H. Pajdała, Komisje sejmowe status i funkcjonowanie, Warszawa 2003, s. 55. 
padku Komisji Edukacji Nauki i Młodzieży są to m.in. podkomisja stała ds. nauki i szkolnictwa wyższego czy też podkomisja stała ds. kształcenia zawodowego.

W każdym przypadku powołanie podkomisji stałej wymaga uzyskania zgody Prezydium Sejmu. Tradycyjnie najwięcej podkomisji stałych powołuje się na początku każdej kadencji parlamentu. Najczęściej z taką inicjatywą i umotywowanym wnioskiem (który powinien zawierać m.in. przedstawienie zakresu działalności proponowanych podkomisji oraz opis czy takie podkomisje działały w poprzedniej kadencji) występuje przewodniczący komisji lub jej prezydium. Jednak mogą to być również np. grupy posłów, pojedynczy posłowie czy też przewodniczący klubów i kół parlamentarnych. Bez zgody Prezydium Sejmu powołanie podkomisji stałej jest niemożliwe.

Prezydium Sejmu podejmuje decyzję i przesyła ją do odpowiedniej komisji. Nie może być sytuacji odwrotnej, kiedy to komisja jako pierwsza podejmuje uchwałę o utworzeniu podkomisji stałej, a następnie występuje o jej akceptację do Prezydium Sejmu ${ }^{6}$. Kwestię tę dobrze obrazuje zamieszanie związane z powołaniem podkomisji stałej do spraw rozwoju i rewitalizacji miast w VII kadencji Sejmu. Z wnioskiem o jej utworzenie zwrócił się do Prezydium Sejmu przewodniczący Klubu Parlamentarnego Platformy Obywatelskiej. Prezydium Sejmu wydało opinię, że powołanie takiej podkomisji stałej spośród członków trzech różnych komisji jest zgodne z regulaminem, jednak nie podjęło wiążącej uchwały w sprawie jej powołania. Tymczasem 12 lutego 2013 r. na wspólnym posiedzeniu Komisji Infrastruktury, Komisji Polityki Społecznej i Rodziny oraz Komisji Samorządu Terytorialnego i Polityki Regionalnej połączone komisje podjęły uchwałę o powołaniu podkomisji stałej oraz ustaliły jej skład ${ }^{7}$. Prezydium Sejmu wyraziło zgodę dopiero 9 maja 2014 r. Niezbędne okazało się więc jeszcze jedno posiedzenie połaczonych komisji i ponowne głosowanie w sprawie utworzenia podkomisji i wyboru jej składu osobowego, które odbyło się 25 września 2014 r. ${ }^{8}$

Powołanie podkomisji stałej (podobnie jak innych rodzajów podkomisji) następuje poprzez przyjęcie przez posłów uchwały o utworzeniu podkomisji oraz o wyborze jej składu osobowego (większością głosów w obecności co najmniej 1/3 liczby członków komisji). Należy podkreślić, że mamy tu do czynienia z różnymi praktykami parlamentarnymi. Najczęściej decyzja o powołaniu podkomisji i o wyborze jej składu jest podejmowana w jednym głosowaniu. Zdarza się jednak, że przewodniczący najpierw poddaje pod głosowanie uchwałę o utworzeniu podkomisji, a dopiero w dalszej kolejności następną uchwałę o wyborze jej składu. Bywają też przypadki, że komisja podejmuje decyzję o powołaniu podkomisji, a następnie przewodniczący ogłasza, że wszyscy chęt-

${ }^{6}$ „Ponieważ utworzenia podkomisji następuje w momencie podjęcia stosownej uchwały przez komisje, należy przyjąć, że zgoda ta powinna być wyrażona uprzednio"; vide P. Czarny, B. Naleziński, Organy Sejmu Rzeczypospolitej Polskiej, Warszawa 2002, s. 88.

${ }^{7}$ Protokół z posiedzenia połączonych Komisji Infrastruktury, Polityki Społecznej i Rodziny oraz Samorządu Terytorialnego i Polityki Regionalnej z 12 lutego 2013 r., VII kadencja Sejmu RP; vide strona internetowa archiwum Sejmu RP <www.sejm.pl/Sejm8.nsf/page.xsp/archiwum>, dostęp 30 XI 2017 [dalej: archiwum Sejmu].

${ }^{8}$ Protokół z posiedzenia połączonych Komisji Infrastruktury, Polityki Społecznej i Rodziny oraz Samorządu Terytorialnego i Polityki Regionalnej z 25 października 2014 r., VII kadencja Sejmu RP; vide archiwum Sejmu. 
ni posłowie mogą zapisywać się do jej składu w sekretariacie komisji (posłów, którzy zgłoszą swój akces w określonym terminie, uznaje się za członków podkomisji) ${ }^{9}$. Uchwały o powołaniu podkomisji stanowią załącznik do protokołu z posiedzenia komisji lub też (znacznie częściej) są po prostu opisywane w protokole z posiedzenia.

Komisje sejmowe posiadają również kompetencje do rozwiązywania podkomisji stałych, co jednak zdarza się bardzo rzadko, np. w VII kadencji Sejmu zlikwidowano przed końcem kadencji jedynie dwie podkomisje stałe.

W doktrynie panuje pogląd, że do likwidacji podkomisji stałej wymagane jest podjęcie uchwały, która przesądzi o jej rozwiązaniu ${ }^{10}$, ale w praktyce postępowanie w takich przypadkach bywa bardzo różne. Na przykład na posiedzeniu Komisji Kultury Fizycznej, Sportu i Turystyki 13 grudnia 2012 r., na którym rozwiązano podkomisje stałą do spraw przygotowań Polski do organizacji Mistrzostw Europy w Piłce Nożnej UEFA EURO $2012^{11}$, nie poddano pod głosowanie uchwały w sprawie rozwiązania podkomisji. Uznano, że wystarczające jest złożenie przez przewodniczącego sprawozdania $\mathrm{z}$ działalności podkomisji ${ }^{12}$. Jeszcze inny przykład to podkomisja stała ds. energetyki ${ }^{13}$ działająca przy Komisji Gospodarki, którą zlikwidowano nie poprzez uchwałę komisji, ale przez decyzję Prezydium Sejmu. Stało się tak, ponieważ Sejm powołał komisję nadzwyczajną ds. energetyki i surowców energetycznych, w związku z czym dalsze funkcjonowanie podkomisji ds. energetyki okazało się bezcelowe. Przewodniczący Komisji Gospodarki wystosował więc pismo do Prezydium Sejmu o wyrażenie zgody na likwidację podkomisji stałej, a pozytywna odpowiedź z dnia 22 października $2014 \mathrm{r}$. została uznana za dzień zakończenia funkcjonowania komisji ${ }^{14}$. Wydaje się, że ze względu na tak różne przykłady działania i duże rozbieżności kwestia rozwiązania podkomisji stałej powinna zostać szczegółowo unormowana w regulaminie Sejmu.

Zakres działań powoływanej podkomisji stałej musi być powiązany z kompetencjami komisji, która ją utworzyła (określonymi w załączniku nr 1 do regulaminu Sejmu). Uważa się, że komisja powołująca podkomisję powinna określić zakres jej zadań,

${ }^{9}$ M.in. podczas drugiego posiedzenia Komisji Obrony Narodowej VII kadencji Sejmu jej przewodniczący poseł S. Niesiołowski ogłosił: „Proszę państwa, przekazuję informacje od prezydium Komisji. Proszę o ewentualne dodatkowe zapisy posłów do poszczególnych podkomisji. Tu nie ma limitów, w związku z czym na razie można się zapisać do wszystkich podkomisji, o ile ktoś tego sobie życzy"; protokół z posiedzenia Komisji Obrony Narodowej z 13 grudnia 2011 r., VII kadencja Sejmu RP, vide archiwum Sejmu.

10 Vide P. Radziewicz, Status podkomisji w świetle Regulaminu Sejmu i praktyki, „Przegląd Sejmowy” 2006, nr 4, s. 54.

${ }^{11}$ Podkomisja stała do spraw przygotowań Polski do organizacji Mistrzostw Europy w Piłce Nożnej UEFA EURO 2012, VII kadencja Sejmu RP, okres działalności od 21 grudnia 2011 r. do 13 grudnia 2012 r.; vide archiwum Sejmu.

${ }_{12}$ Protokół z posiedzenia Komisji Kultury Fizycznej, Sportu i Turystyki z 13 grudnia 2012 r., VII kadencja Sejmu RP; vide archiwum Sejmu.

${ }_{13}$ Podkomisja stała do spraw energetyki, VII kadencja Sejmu RP, działała od 27 stycznia 2012 r. do 22 października 2014 r.; vide archiwum Sejmu.

${ }^{14}$ Pismo z 22 listopada 2014 r. do przewodzącego Komisji Gospodarki W. Jasińskiego, nr GMS-WP014-440/14, podpisane z upoważnienia marszałka Sejmu przez wicemarszałek Sejmu E. Radziszewską; niepublikowane. 
który tylko częściowo wyznacza nazwa komisji ${ }^{15}$. W praktyce przy podejmowaniu uchwały o powołaniu podkomisji stałej jej szczegółowy zakres działania nie zawsze jednak zostaje sformułowany. Zazwyczaj posłowie przyjmuja, że sama nazwa podkomisji stałej wystarczająco określa temat jej prac. Budzi to jednak uzasadnione watpliwości. Podczas powoływania opisywanej już podkomisji stałej ds. rozwoju i rewitalizacji miast zdezorientowani parlamentarzyści pytali przewodniczącego komisji, jaki ma być zakres działania podkomisji. W odpowiedzi usłyszeli, że zakres działań został wskazany we wniosku przewodniczącego klubu parlamentarnego do Prezydium Sej$\mathrm{mu}^{16}$. Takie postępowanie wydaje się mocno kontrowersyjne, ponieważ zgodnie $\mathrm{z}$ art. 165 ust. $1 \mathrm{rS}$ to komisja określa zakres działania powoływanej przez siebie podkomisji. Tak więc powinien on być wyraźnie wskazany w uchwale komisji, a nie jedynie omówiony na jej prezydium czy też opisany we wniosku do Prezydium Sejmu.

Na podstawie art. 26 ust. 1 pkt. 3 u.w.m.p.s., przewodniczący podkomisji stałej dostaje $10 \%$ dodatku do uposażenia poselskiego z tytułu pełnionej funkcji. Ma to z pewnością znaczenie dla Prezydium Sejmu, które podejmuje decyzje w sprawie wyrażenia zgody na powołanie podkomisji. Nadmierne „rozmnożenie” podkomisji stałych byłoby nie tylko nieracjonalne, ale oznaczałoby również zwiększenie wydatków $\mathrm{z}$ budżetu Kancelarii Sejmu.

Zgodnie z art. 165 ust. $1 \mathrm{rS}$, można również utworzyć tzw. podkomisję nadzwyczajna, która powoływana jest tylko na czas pracy nad konkretnym zadaniem i która kończy swoją działalność po jego wykonaniu.

W Sejmie najbardziej powszechne są podkomisje nadzwyczajne do rozpatrzenia projektów ustaw i uchwał, które powołuje się na podstawie odrębnych przepisów. Zgodnie z art. 41 ust. $1 \mathrm{rS}$, „do szczegółowego rozpatrzenia projektu komisje moga powołać podkomisję". Działania i zakres kompetencji tych podkomisji ograniczają się tylko do prac nad danym projektem ustawy bądź uchwały. To właśnie różni je od innych podkomisji nadzwyczajnych. Podkomisja po zakończeniu swoich prac „,przedstawia komisjom sprawozdanie o rozpatrzonym projekcie" i z chwila jego złożenia kończy swoją działalność (art. 41. ust. 2 rS). W skład podkomisji musi wchodzić co najmniej pięciu posłów (art. 41 ust. 1a rS).

15 J.M. Karolczak, Uprawnienia przewodniczqcego podkomisji stałej, [w:] Regulaminu Sejmu w opiniach Biura Analiz Sejmowych, t. II, red. W. Odrowąż-Sypniewski, Warszawa 2010, s. 205.

${ }^{16}$ Protokół z posiedzenia połączonych Komisji Infrastruktury, Polityki Społecznej i Rodziny oraz Samorządu Terytorialnego i Polityki Regionalnej z 25 listopada 2014 r., VII kadencja Sejmu RP — prowadzący obrady przewodniczący Komisji Polityki Społecznej i Rodziny poseł S. Piechota powiedział: „Już wszystko wyjaśniam. Omawiałem to skrótowo, bo myślałem, że wszystko było w wystarczającym stopniu wyjaśnione podczas posiedzenia prezydiów Komisji [...] wniosek przewodniczącego Klubu Parlamentarnego Platforma Obywatelska wskazywał, by powołać taką podkomisję w celu podjęcia prac obejmujących rewitalizację społeczną, infrastrukturalną i architektoniczną miast, a w szczególności zdegradowanych obszarów o szczególnej wartości historycznej, usunięcia zaniedbań istniejących w centrach miast oraz problematyki tzw. blokowisk. Przewodniczący klubu wskazał, iż jak najszybsze podjęcie prac w przedmiotowym zakresie jest konieczne ze względu na narastające problemy związane ze spowolnieniem rozwoju polskich miast. Przywrócenie ich atrakcyjności dla mieszkańców, turystów oraz przedsiębiorców możliwe jest przede wszystkim poprzez podjęcie stosownych inicjatyw legislacyjnych. Czy są uwagi dotyczące zamiaru powołania takiej podkomisji, określenia celu jej działania i składu?”; vide archiwum Sejmu. 
Szczególnym rodzajem podkomisji są podkomisje stałe powoływane przy komisjach nadzwyczajnych do rozpatrywania projektów kodeksów, projektów zmian do kodeksów oraz projektów przepisów wprowadzających kodeksy. W przypadku tych podkomisji regulaminem Sejmu wprowadzono szereg szczegółowych przepisów, które nie mają zastosowania do pozostałych podkomisji. Zgodnie z art. 91 ust. 1 rS, „Komisja Nadzwyczajna może tworzyć podkomisje stałe do szczegółowego rozpatrzenia projektu oraz zespoły robocze, także w ramach podkomisji”' ${ }^{17}$. Do powołania podkomisji stałej przez komisję nadzwyczajną nie jest potrzebna zgoda Prezydium Sejmu. Jedynie podkomisje utworzone przy komisji nadzwyczajnej mogą tworzyć zespoły robocze, co wynika ze specyfiki prac nad projektami kodeksów. Ponadto podkomisje mogą odbywać wspólne posiedzenia (art. 91. ust. $3 \mathrm{rS}$ ) oraz powoływać zespoły stałych ekspertów (art. 92 ust. 2 rS). Wprowadzono również ograniczenie liczby podkomisji, w których może zasiadać członek komisji nadzwyczajnej — nie więcej niż dwóch (art. 91 ust. 2 rS). Bardzo często komisja kodyfikacyjna powołuje po kilka podkomisji stałych, które pracują nad konkretnymi projektami kodeksów.

\section{SKLAD OSOBOWY PODKOMISJI}

Zgodnie $\mathrm{z}$ art. 165 ust. $1 \mathrm{rS}$, w skład podkomisji mogą wchodzić tylko posłowie członkowie komisji, która ją powołała. Oczywiście w trakcie prac ustawodawczych zdarza się, że projekt ustawy zostaje skierowany do kilku komisji, które wspólnie nad nim obraduja $^{18}$. W takiej sytuacji do składu podkomisji wybierani są posłowie ze wszystkich komisji pracujących nad danym projektem. Odbywa się to na zasadzie obyczaju i praktyki parlamentarnej, ponieważ rozwiązanie to nie jest szczegółowo unormowane w regulaminie. Przeważnie prezydia komisji lub ich przewodniczący w trakcie ustalania przebiegu prac nad projektem dogadują się co do składu podkomisji i odpowiedniej, czyli proporcjonalnej reprezentacji członków komisji w jej pracach. Przykładem może być powołana w I kadencji Sejmu Podkomisja Nadzwyczajna do rozpatrzenia projektu uchwały Sejmu w sprawie zmiany regulaminu Sejmu (druk nr 693a) powołana przez cztery komisje: Komisję Administracji i Spraw Wewnętrznych, Komisję Obrony Narodowej, Komisję Regulaminową i Spraw Poselskich oraz Komisję Ustawodawczą. W jej skład weszło łącznie 12 posłów, po trzech z każdej komisji. Podkomisja nadzwyczajna powołana spośród członków kilku komisji składa sprawozdanie o rozpatrzonym projekcie na wspólnym posiedzeniu połączonych komisji ${ }^{19}$.

W VII kadencji Sejmu doszło też do sytuacji, w której powołano — za zgodą Prezydium Sejmu — podkomisje stałe składające się z członków kilku komisji. Pierwszy przypadek to Podkomisja Stała do spraw wykonywania przez Polskę wyroków Europejskiego Trybunału Praw Człowieka utworzona przez Komisję Sprawiedliwości

${ }^{17}$ Uchwała Sejmu RP z dnia 22 grudnia 1995 r. w sprawie zmiany Regulaminu Sejmu Rzeczypospolitej Polskiej (M.P. z 1996 r. nr 1, poz. 3).

${ }^{18}$ Reguluje to art. 40 ust. 2 rS, „Komisje, do których skierowany został do rozpatrzenia projekt, obradują nad nim wspólnie".

${ }^{19} \mathrm{~W}$ art. 41 ust. 2 rS jest mowa o składaniu sprawozdania „komisjom”, a nie tylko „komisji”. 
i Praw Człowieka oraz Komisję Spraw Zagranicznych. Drugi przypadek to Podkomisja Stała do spraw rozwoju i rewitalizacji miast powołana przez Komisję Infrastruktury, Komisję Polityki Społecznej i Rodziny oraz Komisję Samorządu Terytorialnego i Polityki Regionalnej.

Zgodnie z art. 41 ust. 1a rS, w skład podkomisji nadzwyczajnej do szczegółowego rozpatrzenia projektu ustawy lub uchwały musi wchodzić co najmniej pięciu posłów. Przepis ten wprowadzono do regulaminu dopiero w $2008 \mathrm{r}^{20}$ Podczas debaty nad projektem uchwały poseł sprawozdawca podkreślał, że zmiana ta ma zapewnić większą reprezentację klubów parlamentarnych w podkomisjach ${ }^{21}$. Na porządku dziennym były bowiem przypadki, że podkomisje nadzwyczajne były powoływane w składach 3-osobowych ${ }^{22}$, co oznaczało, że nie wszystkie kluby i koła parlamentarne mogły być reprezentowane w pracach podkomisji. Brak jednego posła na posiedzeniu oznaczał, że decyzje dotyczące ustawy były podejmowane jedynie przez dwie osoby, co budziło duże kontrowersje. Należy też podkreślić, że przyczyną wprowadzenia tego przepisu do regulaminu Sejmu były również problemy z frekwencją i brakiem kworum na posiedzeniach podkomisji nadzwyczajnych obradujących w składzie 3-osobowym.

Na marginesie można przytoczyć przykład kuriozalnej sytuacji z I kadencji Sejmu, kiedy stała podkomisja działała w 2-osobowym składzie. Komisja Obrony Narodowej utworzyła 10 stycznia 1992 r. Podkomisję Stałą do spraw doktryny obronnej, w której skład wchodziło trzech posłów. Jeden z członków komisji, Janusz Onyszkiewicz, 19 września 1992 r. zrezygnował jednak z pracy w komisji w związku z objęciem funkcji sekretarza stanu w Ministerstwie Obrony Narodowej. Na jego miejsce nie powołano żadnego nowego członka i podkomisja w 2-osobowym składzie działała aż do zakończenia kadencji ${ }^{23}$.

Najczęściej skład osobowy podkomisji nadzwyczajnej powołanej do prac nad projektem ustawy lub uchwały ustala się zgodnie z zasadą proporcjonalnej reprezentacji klubów i kół parlamentarnych. Praktyka VI i VII kadencji wskazuje, że zazwyczaj były to grupy 7-osobowe, po trzech posłów z Klubu Parlamentarnego PO, dwóch z Klubu Parlamentarnego PiS oraz po jednym z Klubu Parlamentarnego SLD i PSL ${ }^{24}$. Koalicja miała więc w tym układzie przewagę jednego głosu nad opozycją. Rzadko zdarzało się,

${ }^{20}$ Uchwała z dnia 19 grudnia 2008 r. w sprawie zmiany Regulaminu Sejmu Rzeczypospolitej Polskiej (M.P. z 2008 r. nr 2, poz. 9).

${ }^{21}$ Stenogram z 28. posiedzenia Sejmu VI kadencji z 5 listopada 2008 r., wstapienie posła J. Budnika podczas debaty w trakcie drugiego czytania uchwały w sprawie zmiany regulaminu Sejmu; vide archiwum Sejmu.

${ }^{22}$ Szczególnie dużo podkomisji w składzie 3-osobowym powoływano w I i II kadencji Sejmu.

23 Vide Informacja o pracy Komisji Obrony Narodowej w okresie I kadencji Sejmu RP (1991-1993), Warszawa 1993.

${ }^{24}$ Czasami taki układ sił rodzi jednak pewien kłopot, zwłaszcza w przypadku małych klubów mających tylko jednego lub dwóch przedstawicieli w danej komisji, którzy muszą zasiadać w wielu podkomisjach nadzwyczajnych, np. na posiedzeniu Komisji Sprawiedliwości i Praw Człowieka posłowie narzekali, że kolejny raz jest wakat w składzie, z powodu nieobecności w komisji jedynego posła Klubu Poselskiego PSL. Biuletyn Komisji Sprawiedliwości i Praw Człowieka z 19 listopada 2008 r., VI kadencja Sejmu RP; vide archiwum Sejmu. 
aby miejsce w podkomisji przypadło przedstawicielom kół poselskich, chyba że miała bardzo liczny skład lub któryś z klubów odstapił swoje miejsce posłowi z koła.

Skład osobowy podkomisji stałych jest kształtowany w bardzo różny sposób. Na przykład w trzech podkomisjach stałych Komisji Obrony Narodowej (ds. współpracy z zagranicą i NATO; ds. budżetu, infrastruktury i zaopatrzenia wojska; ds. problemów społecznych wojska) praktyką jest, że może zapisać się do nich każdy członek komisji, a funkcje przewodniczących przypadły odpowiednio klubom: PiS, PSL i PO. Natomiast w Podkomisji stałej ds. partnerstwa wschodniego działającej przy Komisji Spraw Zagranicznych ustalono 7-osobowy skład i parytet udziału poszczególnych frakcji parlamentarnych według opisanego modelu 3-2-1-1.

Skład osobowy podkomisji (zarówno stałych, jak też nadzwyczajnych) często ulega zmianom. Po pierwsze, może się to wiązać z wygaśnięciem mandatu posła w trakcie kadencji. Po drugie, może dotyczyć sytuacji objęcia przez posła funkcji członka Rady Ministrów lub sekretarza stanu. Po trzecie, może się to wiązać ze zmianami w składach osobowych komisji sejmowych (do czego niezbędna jest stosowna uchwała Sejmu). Opuszczenie przez posła danej komisji jest jednoznaczne z utratą członkostwa w jej podkomisjach. Po czwarte wreszcie, może dotyczyć złożenia przez posła rezygnacji z zasiadania $\mathrm{w}$ podkomisji.

\section{PREZYDIUM PODKOMISJI}

Do 2008 r. brakowało w regulaminie Sejmu wskazania wprost, które unormowania dotyczące komisji sejmowych mają zastosowanie również do podkomisji, co oceniano bardzo krytycznie. Taka sytuacja budziła wątpliwości, a odmienne interpretacje często prowadziły do sporów między posłami. W doktrynie panował jednak dość jednolity pogląd, że jeśli w przepisach regulaminowych przewidziano szczegółowe rozwiązania odnoszące się do działalności komisji sejmowych, to rozwiązanie to — w przypadku braku odmiennego przepisu regulaminu — odpowiednio stosuje się również do podkomisji ${ }^{25}$. Szczegółowe rozwiązania w tym zakresie wprowadzono dopiero uchwałą z dnia 19 grudnia 2008 r. w sprawie zmian regulaminu Sejmu. Obecnie — zgodnie z art. 165 ust. 2 rS - w pracach podkomisji odpowiednie zastosowanie mają przepisy dotyczące komisji sejmowych, czyli artykuły: 149, 150, 151, 152 ust. 1, 154 ust. 1, 1a, 3 i 5, 155, 156 i art. 163a ust. 1 rS. Regulacje te niestety nie przyczyniły się do rozwiązania wszystkich spornych kwestii dotyczących trybu pracy podkomisji, a czasami wręcz je komplikowały.

Wyboru prezydium podkomisji dokonuje się na pierwszym posiedzeniu podkomisji w głosowaniu jawnym większością głosów. W praktyce najczęściej pierwsze zebranie zwołuje przewodniczący komisji zaraz po zakończeniu obrad, na których podkomisję powołano. Również przewodniczący komisji proponuje kandydata na funkcję

25 Vide M. Zubik, Organizacja..., s. 313; P. Radziewicz, Status..., s. 56; J.M. Karolczak, Uprawnienia przewodniczacego..., s. 205; P. Chybalski, Pojęcie , osoby wykonujacej zawodowa działalność lobbingowa”" w zwiazku z art. 154 ust. 2 a i 2 d regulaminu Sejmu oraz osoby uprawnione do uczestnictwa w posiedzeniu podkomisji, [w:] Regulamin Sejmu w opiniach Biura Analiz Sejmowych..., s. 255. 
przewodniczącego podkomisji, po przeprowadzeniu wcześniejszych konsultacji z przedstawicielami klubów parlamentarnych. Bardzo rzadko dochodzi do sytuacji, że pojawia się kilku kandydatów ${ }^{26}$. Zazwyczaj wszystko jest ustalone wcześniej, a samo głosowanie jest raczej formalnością. Zdarza się też, że na pierwszym posiedzeniu podkomisji wybiera się tylko przewodniczącego, a jego zastępca powoływany jest dopiero na kolejnym spotkaniu.

W przypadku podkomisji stałych stosowane są też inne praktyki wyboru przewodniczących podkomisji. Przykładem może być Komisja Obrony Narodowej VII kadencji Sejmu, której członkowie dokonali wyboru przewodniczących trzech podkomisji stałych na posiedzeniu komisji w dniu 13 grudnia 2011 r. W głosowaniu wzięli udział wszyscy członkowie komisji, w tym również ci, którzy nie wchodzili w skład podkomisji ${ }^{27}$, co jest zresztą zgodne z interpretacją Prezydium Sejmu. W piśmie z dnia 23 sierpnia 2006 r. w sprawie zgody na powołanie Podkomisji stałej ds. nauki i szkolnictwa wyższego ówczesny wicemarszałek Sejmu, Bronisław Komorowski, napisał: „Jednocześnie informuję, że Prezydium Sejmu stoi na stanowisku, że podmiotami uprawnionymi do wyboru przewodniczącego podkomisji są Komisja powołująca podkomisję albo sama podkomisja"28.

W skład prezydium podkomisji nadzwyczajnych wchodzą przewodniczący oraz najczęściej jeden zastępca przewodniczącego. W większości przypadków przewodniczący podkomisji do rozpatrzenia projektu ustawy lub uchwały pochodzi z klubu reprezentującego większość parlamentarną (zwłaszcza przy pracach nad projektami rządowymi), choć zdarzają się wyjątki (zazwyczaj przy niekontrowersyjnych ustawach popieranych przez wszystkie kluby i koła) ${ }^{29}$.

Zgodnie $\mathrm{z}$ art. 165 ust. $2 \mathrm{rS}$, w pracach podkomisji odpowiednie zastosowanie maja przepisy dotyczące komisji sejmowych ${ }^{30}$. Tym samym na podstawie art. $150 \mathrm{rS}$ pracami podkomisji powinno kierować kolegialnie prezydium, które m.in.: opracowuje projekty planów pracy podkomisji, ustala terminy i porządek dzienny posiedzeń oraz czuwa nad ich przygotowaniem, a także zapewnia członkom podkomisji otrzymywanie w odpowiednim czasie należycie przygotowanych materiałów. Prezydium podkomisji ustalając porządek dzienny posiedzenia, powinno brać pod uwagę wnioski klubów

${ }^{26}$ Jako wyjątkowy przykład wyboru spośród dwóch zgłoszonych kandydatur na przewodniczącego podkomisji można podać głosowanie za J. Zakrzewską (PO) lub M. Opiołą (PiS) podczas pierwszego posiedzenia podkomisji nadzwyczajnej do rozpatrzenia rządowego projektu ustawy o zmianie ustawy o przebudowie i modernizacji technicznej oraz finansowaniu Sił Zbrojnych Rzeczypospolitej Polskiej oraz ustawy o finansach publicznych (druk nr 3190). Głosowanie wygrała poseł J. Zakrzewska; vide archiwum Sejmu.

${ }^{27}$ Protokół z posiedzenia Komisji Obrony Narodowej z 13 grudnia 2011 r., VII kadencja Sejmu RP; vide archiwum Sejmu.

${ }^{28}$ Pismo wicemarszałka Sejmu B. Komorowskiego z 23 sierpnia 2006 r. do przewodniczącej Komisji Edukacji, Nauki i Młodzieży K. Szumilas, nr PS-157-156/06; niepublikowane.

${ }_{29}$ Vide więcej M. Kamiński, Status prawny klubów i kót parlamentarnych w Sejmie RP, Torun 2015, s. $83-88$.

${ }^{30}$ Chodzi o art. 149, 150,151, 152 ust. 1, art. 154 ust. 1, 1a, 3 i 5, art. 155, 156 i art. 163a ust. 1 rS. Przepis ten wprowadzono uchwałą z dnia 19 grudnia 2008 r. w sprawie zmiany regulaminu Sejmu, ponieważ wcześniej różnie interpretowano regulamin Sejmu. 
i kół poselskich oraz poszczególnych posłów. Niestety w praktyce parlamentarnej przepisy dotyczące kolegialnego sprawowania kierownictwa przez prezydium podkomisji (zwłaszcza w podkomisjach nadzwyczajnych do prac nad projektem ustawy bądź uchwały) często nie są realizowane. Kluczowy jest w tym zakresie przepis art. 150 ust. $5 \mathrm{rS}$, zgodnie z którym „Prezydium komisji podejmuje uchwały większością głosów. W wypadku równej liczby głosów decyduje głos przewodniczącego komisji". Najczęściej prezydium podkomisji stanowi skład 2-osobowy (przewodniczący i jego zastępca), przy czym przewodniczącym jest przedstawiciel klubu reprezentującego większość parlamentarną. Wynik głosowania w spornych kwestiach jest więc łatwy do przewidzenia, a rola wiceprzewodniczącego podkomisji jest poważnie ograniczona. Taka sytuacja powoduje, że na porządku dziennym są praktyki, kiedy przewodniczący podkomisji bez żadnych konsultacji z wiceprzewodniczącym podejmuje decyzje o zwołaniu posiedzenia i porządku pracy podkomisji czy też samodzielnie występuje o opinie i analizy prawne.

Przepisy te rodzą jeszcze większy problem, ponieważ ze względu na ułomność rozwiązań regulaminowych możliwy jest mechanizm blokowania ustaw w podkomisji (zwany potocznie „zamrażarką podkomisji”). Przewodniczący podkomisji z własnej inicjatywy może nie zwoływać posiedzeń podkomisji i w ten sposób blokować prace nad ustawa. Dodatkowo kluby opozycyjne nie mogą w tym przypadku skorzystać $\mathrm{z}$ art. 152 ust. 2 rS, pozwalającego na zwołanie posiedzenia na wniosek 1/3 ogólnej liczby członków, ponieważ nie dotyczy on podkomisji. Jako przykład blokowania projektów ustaw w podkomisji w VI kadencji Sejmu można podać poselski projekt ustawy o zmianie ustawy o uprawnieniach do bezpłatnych i ulgowych przejazdów środkami publicznego transportu zbiorowego (druk $\mathrm{nr} 1889)^{31}$ czy też poselski projekt ustawy o licencjach prawniczych i świadczeniu usług prawniczych (druk $\mathrm{nr} 680)^{32}$. Należy jednak podkreślić, że mechanizm ten stosowany był nagminnie we wszystkich kadencjach Sejmu RP.

Skutecznym sposobem na ukrócenie tego typu praktyk mogłoby być wprowadzenie w regulaminie Sejmu możliwości zwoływania posiedzeń podkomisji na wniosek 1/3 ogólnej liczby jej członków, zgodnie z art. 152 ust. 2 rS (tak jak jest w przypadku komisji). Po złożeniu takiego wniosku przewodniczący podkomisji byłby zobowiązany do zwołania posiedzenia podkomisji w ciagu 30 dni od daty jego wpłynięcia. Dzięki takiemu rozwiązaniu kluby i koła parlamentarne uzyskałyby większy wpływ na przyspieszenie procesu ustawodawczego w przypadku konkretnych projektów ustaw.

31 Poselski projekt ustawy o zmianie ustawy o uprawnieniach do bezpłatnych i ulgowych przejazdów środkami publicznego transportu zbiorowego (druk nr 1889) został złożony 24 lutego 2009 r., pierwsze czytanie na posiedzeniu Sejmu odbyło się 19 czerwca 2009 r. Następnie projekt skierowano do Komisji Finansów Publicznych oraz Komisji Infrastruktury. Podczas posiedzenia komisji w dniu 10 lutego 2010 r. powołano podkomisję nadzwyczajną do pracy nad projektem. Od tego czasu do dnia 1 października 2010 r. podkomisja została zwołana tylko raz, a prace nad projektem de facto zostały zablokowane.

32 Poselski projekt ustawy o licencjach prawniczych i świadczeniu usług prawniczych (druk nr 680) został złożony 30 stycznia 2008 r., do pierwszego czytania skierowano go na posiedzeniu Sejmu 27 czerwca 2008 r. Następnie skierowano go do Komisji Sprawiedliwości i Praw Człowieka, gdzie na posiedzeniu komisji 25 lipca 2008 r. powołano podkomisję nadzwyczajną. Od tego czasu do dnia 1 września 2010 r. podkomisja została zwołana tylko raz, a prace nad projektem de facto zostały zablokowane. 
Komisje sejmowe mają możliwość wpływania na mobilizowanie członków powołanej przez siebie podkomisji do bardziej efektywnej i szybszej pracy. Komisja może np. zwołać swoje posiedzenie, którego jedynym punktem byłoby przedstawienie przez przewodniczącego podkomisji szczegółów dotychczasowych prac podkomisji (co może wpłynąć na podkomisję mobilizująco). Komisja ma też prawo zmienić uchwałę o powołaniu podkomisji, dodając ostateczny termin, do którego podkomisja musi zakończyć swoje prace i przedłożyć sprawozdanie. Wreszcie komisja może podjąć uchwałę o rozwiązaniu podkomisji, powołaniu nowej, wymianie wszystkich jej członków lub odwołaniu przewodniczącego z jej składu. W praktyce parlamentarnej komisje sejmowe korzystaja z tych uprawnień niezwykle rzadko.

Regulamin Sejmu zawiera również pewną lukę, która może doprowadzić do paraliżu prac podkomisji w przypadku wakatu na stanowisku przewodniczącego, np. przez złożenie rezygnacji z prac w podkomisji czy też zmianę komisji. W takiej sytuacji - zgodnie z art. 150 ust. $3 \mathrm{rS}$ - obrady podkomisji powinien poprowadzić jeden z zastępców przewodniczącego. Jednak w przypadku, kiedy zastępców jest np. dwóch i nie mogą oni osiagnąć konsensu, dochodzi do sytuacji patowej. Piotr Chybalski w swojej opinii napisał, „z przepisów regulaminowych nie sposób wywieść reguły, która określałaby wprost osobę odpowiedzialną za kierowanie pracami prezydium w sytuacji wakatu na stanowisku przewodniczącego"33. Z przepisów regulaminu nie da się więc wywieść, kto ma być tym zastępca. Logiczne wydaje się, że do odblokowania prac konieczne jest jak najszybsze zwołanie posiedzenia podkomisji i wybór nowego przewodniczącego. Jednak powstaje problem, kto takie posiedzenie powinien zwołać, jeżeli prezydium podkomisji nie może podjąc decyzji wskutek braku konsensu. W analogicznej sytuacji odnoszącej się do komisji sejmowej, zgodnie z art. 152 ust. 3 rS, posiedzenie może zwołać Prezydium Sejmu (obradom może wówczas przewodniczyć marszałek Sejmu lub upoważniony przez niego wicemarszałek). Natomiast artykuł ten w odniesieniu do podkomisji nie ma zastosowania. Brak wskazania osoby odpowiedzialnej może zupełnie sparaliżować pracę podkomisji. Rozwiązaniem wydaje się jedynie interwencja komisji przez podjęcie decyzji o rozwiązaniu podkomisji, a następnie jej ponownym powołaniu, wyborze składu osobowego oraz zwołaniu pierwszego posiedzenia, na którym ukonstytuuje się nowe prezydium podkomisji.

\section{POSIEDZENIA PODKOMISJI}

Podkomisje obradują na posiedzeniach, które są wyznaczane w terminach określonych przez samą podkomisję, jej prezydium lub przewodniczącego. Podkomisje mogą też odbywać wspólne posiedzenia, którym przewodniczy jeden z przewodniczących podkomisji (art. 149, 152 i 162 rS). Zazwyczaj w takich przypadkach przewodniczący podkomisji ustalają między sobą, który z nich ma prowadzić obrady ${ }^{34}$.

${ }^{33}$ P. Chybalski, Sposób kierowania obradami komisji sejmowej oraz jej prezydium w sytuacji wakatu na stanowisku przewodniczacego komisji, [w:] Regulaminu Sejmu w opiniach Biura Analiz Sejmowych..., s. 211.

${ }^{34}$ Podobnie jest w przypadku wspólnych posiedzeń komisji sejmowych, decydująca jest zazwyczaj wielkość komisji. 
Podkomisje mogą też odbywać posiedzenia wyjazdowe, z czego korzystają zwłaszcza podkomisje stałe ${ }^{35}$.

Posiedzenia podkomisji są jawne, jednak podkomisja może również postanowić o odbyciu posiedzenia zamkniętego. W art. 154 ust. 1 rS przyznano prawo uczestnictwa w posiedzeniach podkomisji (w tym również zamkniętych) posłom niebędących jej członkami. Mogą oni zabierać głos w dyskusji i składać wnioski, ale nie moga brać udziału w głosowaniu. Ponadto na posiedzeniach podkomisji mogą być obecni — z prawem głosu w dyskusji — wybrani w Rzeczypospolitej Polskiej posłowie do Parlamentu Europejskiego (art. 154 ust. 1a rS). Zgodnie z art. 154 ust. 3 rS, rozszerzono katalog osób, które mogą wziąć udział w posiedzeniu podkomisji, o przedstawicieli organizacji zawodowych i społecznych oraz ekspertów podkomisji, a także inne osoby. Warunkiem udziału w posiedzeniu jest uzyskanie zaproszenia od prezydium podkomisji lub jej przewodniczącego, którzy mogą wystosować je niezależnie od siebie. Dodatkowo na posiedzeniu podkomisji moga być obecni — za zgoda jej przewodniczącego - pracownicy biur klubów poselskich oraz dziennikarze z prasy, radia i telewizji. Również w tym przypadku udział tych osób w obradach podkomisji uzależniony jest od decyzji przewodniczącego. Podkomisja nie może skutecznie tego prawa ograniczyć (oczywiście dotyczy to sytuacji, kiedy posiedzenie podkomisji odbywa się w trybie jawnym).

Natomiast — zgodnie z art. 154 ust. 2d rS — nie mają prawa uczestnictwa w posiedzeniach podkomisji osoby wykonujące zawodową działalność lobbingową oraz osoby uprawnione do reprezentowania podmiotu wykonującego zawodową działalność lobbingową (takie prawo przysługuje im tylko w przypadku posiedzeń komisji sejmowych) ${ }^{36}$. Fundacja im. Stefana Batorego w raporcie z realizacji projektu, zatytułowanym „Społeczny monitoring procesu stanowienia prawa”, podkreśla, że w posiedzeniach podkomisji mogą swobodnie uczestniczyć niezarejestrowani lobbyści korzystający z instytucji gościa. ,Tworzy to nierówność praw podmiotów, a ponadto premiuje działania pozaprawne" ${ }^{37}$. W raporcie znalazła się też uwaga, że ,,przedstawiciele organizacji pozarządowych uczestniczący w posiedzeniach podkomisji często nie orientują się, kto jest ekspertem, a kto gościem, kto reprezentantem grupy interesu, a kto lobbystą" ${ }^{38}$. Raportujący uważają też, że proces wyłaniania ekspertów komisji jest nietransparentny.

Z posiedzenia podkomisji nie sporządza się sprawozdań ani biuletynów, ale są one nagrywane przez pracowników sekretariatu komisji. Tylko część posiedzeń podkomisji — tych, które odbywają się w odpowiednich salach sejmowych — jest na-

${ }^{35} \mathrm{~Np}$. w VII kadencji Sejmu podkomisja stała ds. polskiego przemysłu obronnego oraz modernizacji technicznej Sił Zbrojnych, powołana przy Komisji Obrony Narodowej, odbyła kilkanaście wyjazdowych posiedzeń, wizytując zakłady zbrojeniowe w różnych częściach Polski.

${ }^{36}$ Regulacje prawne dotyczące osób wykonujących zawodową działalność lobbingową uregulowano w ustawie z dnia 7 lipca 2005 r. o działalności lobbingowej w procesie stanowienia prawa (Dz.U. z 2005 r. nr 169, poz. 1414, ze zm.).

${ }^{37}$ Fundacja im. Stefana Batorego, Przejrzystość procesu stanowienia prawa. Raport z realizacji projektu ,,Spoleczny monitoring procesu stanowienia prawa”, Warszawa 2008, s. 41.

38 Ibidem, s. 61. 
grywana przez służby Kancelarii Sejmu za pomocą urządzeń rejestrujących obraz i dźwięk oraz jest dostępna on-line na stronach internetowych parlamentu. System ten bardzo często jest poddawany krytyce. Fundacja im. Stefana Batorego w swoim raporcie oceniła, że „Prace podkomisji, w których odbywa się główna praca legislacyjna na poziomie sejmowym, są wyłącznie nagrywane, a tylko wyjątkowo protokołowane. W rezultacie poprawki wnoszone przez posłów czy proponowane przez gości podkomisji — a przyjmowane przez posłów — nie są jednoznacznie autoryzowane. W razie pomyłek czy działań celowych trudno znaleźć autora zmian wprowadzanych do tworzonych aktów prawnych"39.

W doktrynie postuluje się, aby wymogi dotyczące sporządzania szczegółowego sprawozdania z posiedzenia komisji $\left(\operatorname{art} .166 \mathrm{rS}^{40}\right.$ ) stosować również do podkomisji. Jak podkreśla $P$. Radziewicz, ,brak transparentności prac podkomisji sprzyja rozmywaniu odpowiedzialności politycznej posłów za sposób wykonywania mandatu oraz umożliwia udział przy tworzeniu prawa podmiotom do tego formalnie nieuprawnionym" " Zgadzam się z tym poglądem. Mimo że brak szczegółowego sprawozdania daje posłom większą swobodę wyrażania własnych poglądów (często niezależnych od klubu parlamentarnego), to jawność życia publicznego powinna jednak wziąć górę. W dzisiejszych czasach nic nie stoi na przeszkodzie, aby wszystkie posiedzenia podkomisji były rejestrowane i udostępniane na stronie internetowej Sejmu RP.

Podobnie jest z kwestią jawności informacji o obecności posłów na posiedzeniach podkomisji. W regulaminie Sejmu wprowadzono obowiązek potwierdzenia przez posła uczestnictwa w posiedzeniu komisji lub podkomisji podpisem na liście obecności (art. 7 ust. $6 \mathrm{rS}$ ), ale w praktyce egzekwowanie tego obowiązku rodzi pewne problemy. W przeciwieństwie do posiedzeń komisji, w przypadku których dane o nieobecnościach posłów sa jawne, to $\mathrm{w}$ odniesieniu do podkomisji nie są one upubliczniane ani na stronie internetowej Sejmu RP, ani w sprawozdaniach komisji, co przyczynia się do niskiej frekwencji posłów (zwłaszcza podczas posiedzeń podkomisji stałych). Taka sytuacja jest niewskazana i powinna ulec zmianie.

\section{ZAKRES ZADAŃ PODKOMISJI}

Nie ulega wątpliwości, że podkomisje przyczyniają się do usprawnienia działalności komisji przez umożliwienie posłom pracy w mniejszych grupach roboczych. To rozsądne rozwiązanie z uwagi na fakt, że niektóre duże komisje sejmowe liczą po kilkudziesięciu posłów (np. Komisja Finansów Publicznych w VII kadencji Sejmu liczyła 55 posłów). Szczegółowa praca nad projektami ustaw, zwłaszcza przy obszernych

39 Ibidem, s. 46.

${ }^{40}$ Art. 166 ust. 1 rS: „Z przebiegu każdego posiedzenia komisji sporządza się protokół, który stanowi urzędowe stwierdzenie przebiegu obrad”. Art. 166 ust. 2: „Protokół obejmuje krótki opis przebiegu posiedzenia, a w załączniku zredagowany stylistycznie pełny zapis jego przebiegu. Do protokołu załącza się także listy obecności, teksty projektów, przyjętych sprawozdań, uchwał, opinii, dezyderatów oraz teksty poprawek zgłoszonych w formie pisemnej do projektów ustaw i uchwał, teksty przedłożonych odpowiedzi, informacji i innych materiałów".

41 P. Radziewicz, Status..., s. 57. 
nowelizacjach, byłaby w takim składzie nieefektywna. Tymczasem mniejsze zespoły posłów (podkomisje liczą zazwyczaj od pięciu do siedmiu osób) mogą uporać się z tą kwestią znacznie skuteczniej.

Analiza sprawozdań z posiedzeń komisji sejmowych z lat 1991-2015 (od I do VII kadencji Sejmu) wyraźnie wykazała, że zakres zadań stawianych przed podkomisjami jest dużo szerszy. Ogólnie podkomisje nadzwyczajne możemy podzielić na kilka grup tematycznych, wyróżnionych ze względu na charakter ich działań ${ }^{42}$.

Pierwsza grupa obejmuje podkomisje nadzwyczajne związane z przebiegiem procesu ustawodawczego.

Oprócz podkomisji do szczegółowego rozpatrzenia projektu ustawy lub uchwały (powołanej w trybie art. $41 \mathrm{rS}$ ) możemy wyróżnić w tej grupie również:

- podkomisje do przygotowania komisyjnego projektu ustawy lub uchwały. Ich praca wynika $\mathrm{z}$ art. 32 ust. $2 \mathrm{rS}$, w którym komisjom sejmowym przyznano prawo inicjatywy ustawodawczej. Często takie projekty ustaw lub uchwał są wypracowywane na posiedzeniach podkomisji. W kadencjach I-VII powołano 69 podkomisji ds. komisyjnego projektu ustawy ${ }^{43}$ oraz 11 podkomisji ds. rozpatrzenia uchwały;

- podkomisje do przeglądu prawa i przygotowania sprawozdania w zakresie potrzeby zmian legislacyjnych. Są to raczej rzadko powoływane podkomisje, łącznie powstały tylko cztery (w III i IV kadencji Sejmu) ${ }^{44}$;

— podkomisje do opracowania opinii dla innej komisji o projekcie ustawy lub uchwały. Ich działalność wynika z art. 42 ust. 1 rS, zgodnie z którym ,przy rozpatrywaniu projektów ustaw (uchwał) komisje i podkomisja biorą pod uwagę opinie przedstawione przez inne komisje sejmowe i posłów". Łącznie w kadencjach I-VII powołano 21 tego typu podkomisji ${ }^{45}$.

${ }^{42}$ Wszystkie dane dotyczące zakresu prac podkomisji pochodzą z analiza sprawozdań komisji sejmowych od I do VII kadencji Sejmu (1991-2015). Spis sprawozdań komisji sejmowych wykorzystanych w badaniach własnych nad praktyką działania podkomisji w Sejmie RP dostępny na stronie < www.researchgate.net/ publication/325450845>.

${ }^{43}$ M.in. w IV kadencji Sejmu Komisja Samorządu Terytorialnego wspólnie z Komisją Polityki Regionalnej oraz Komisją Ustawodawczą utworzyły Podkomisję Nadzwyczajną do opracowania projektu ustawy o zmianie ustaw - Ordynacja wyborcza do rad gmin, rad powiatów i sejmików województw oraz o bezpośrednim wyborze wójta, burmistrza, prezydenta miasta.

${ }^{44}$ W III kadencji działały: Podkomisja Nadzwyczajna ds. przeglądu systemu podatkowego w obszarze kultury fizycznej i sportu (powołana przez Komisję Kultury Fizycznej i Turystyki); Podkomisja Nadzwyczajna do przygotowania sprawozdania o zakresie potrzebnych zmian legislacyjnych, dotyczących cyfrowej technologii przekazu (powołana przez Komisję Kultury i Środków Przekazu oraz Komisję Transportu i Łączności) oraz Podkomisja Nadzwyczajna ds. przeglądu obecnie obowiązujących ustaw w zakresie wsparcia kapitałowego istniejących i tworzonych funduszy poręczeń kredytowych poprzez dofinansowanie ze środków publicznych i ze środków pomocowych w kontekście małych i średnich przedsiębiorstw (powołana przez Komisję Małych i Średnich Przedsiębiorstw). Natomiast w IV kadencji działała Podkomisja Nadzwyczajna do przeglądu prawa oświatowego pod kątem przeciwdziałania zjawiskom patologicznym w szkole i opracowania propozycji zmian w tym zakresie (powołana przez Komisję Edukacji, Nauki i Młodzieży).

${ }^{45}$ M.in. w IV kadencji Sejmu Komisja Polityki Społecznej i Rodziny utworzyła Podkomisję Nadzwyczajną do opracowania projektu opinii Komisji dotyczącej rządowego projektu ustawy o nadzorze ubezpieczeniowym i emerytalnym oraz Rzeczniku Ubezpieczonych (druk nr 584). 
Kolejna grupa podkomisji nadzwyczajnych dotyczy przygotowania projektów uchwał wymienionych w art. 158 rS, zgodnie z którym ,komisja uchwala dezyderaty, opinie, sprawozdania, a także projekty uchwał, rezolucji, apeli, oświadczeń lub deklaracji Sejmu".

W praktyce parlamentarnej powoływano wyłącznie podkomisje do opracowania:

- komisyjnych projektów dezyderatów (8 podkomisji) ${ }^{46}$,

- komisyjnych projektów opinii (11 podkomisji) ${ }^{47}$,

— komisyjnych projektów stanowisk (12 podkomisji $)^{48}$,

Jako osobny rodzaj podkomisji z tej grupy należy wymienić podkomisję do wewnętrznych rozstrzygnięć w komisji. Mają one wyjątkowy charakter, ponieważ są powoływane w celu rozwiązania problemu, który powstał podczas prac komisji i którego nie dało się rozstrzygnać podczas posiedzenia. Konieczne stało się więc utworzenie podkomisji do opracowania kompromisowych rozwiązań. Były właściwie tylko dwa takie przypadki. W II kadencji Sejmu przy Komisji Kultury i Środków Przekazu utworzono:

- Podkomisję Nadzwyczajną do opracowania metod i sposobów analizowania przez Komisję Kultury i Środków Przekazu problemów telewizji publicznej;

- Podkomisję Nadzwyczajną do opracowania nazwy i zakresu działania podkomisji dotyczącej problematyki radiofonii i telewizji.

Następna grupa podkomisji nadzwyczajnych możliwa do wyodrębnienia ze względu na zakres działań to podkomisje związane z kontrola, monitoringiem oraz badaniem określonych spraw. Nie są to podkomisje powoływane często, ale odgrywają dość ważną rolę.

Możemy je podzielić na:

- podkomisje do monitorowania i oceniania programów rządowych oraz kontroli wykonywania ustaw. Ich praca wynika z art. 151 ust. 1 pkt. 3 rS, na podstawie którego komisje analizują działalność poszczególnych działów administracji i gospodarki państwowej. Natomiast zgodnie z art. 161 ust. $1 \mathrm{rS}$, „w sprawach związanych z wprowadzeniem w życie i wykonywaniem ustaw i uchwał Sejmu właściwe komisje przeprowadzają kontrole". Łącznie w okresie od I do VII kadencji powołano siedem tego typu podkomisji ${ }^{49}$;

${ }^{46}$ M.in. w III kadencji Sejmu Komisja Polityki Przestrzennej Budowlanej i Mieszkaniowej powołała Podkomisję Nadzwyczajną do opracowania dezyderatu Komisji w sprawie wymiany handlowej w sferze usług budowlanych między Polską a RFN.

${ }^{47}$ M.in. w I kadencji Sejmu Komisja Kultury i Środków Przekazu wspólnie z Komisją Regulaminową i Spraw Poselskich powołały Podkomisję Nadzwyczajną do opracowania projektu opinii w sprawie relacjonowania przez publiczną telewizję i radio obrad Sejmu i jego działalności.

${ }^{48}$ M.in. w II kadencji Sejmu Komisja Polityki Społecznej utworzyła Podkomisję Nadzwyczajną do opracowania stanowiska Komisji w sprawie promowania produktywnego zatrudnienia i zmniejszenia bezrobocia.

${ }^{49}$ M.in. w IV kadencji Sejmu RP Komisja Rolnictwa i Rozwoju Wsi powołała Podkomisję Nadzwyczajną do spraw monitorowania wdrażania Zintegrowanego Systemu Zarządzania i Kontroli (IACS), a w VI kadencji Podkomisję Nadzwyczajną do monitorowania realizacji programu upraw roślin motylkowych. Natomiast w II kadencji Komisja Polityki Przestrzennej, Budowlanej i Mieszkaniowej utworzyła dwie 
- podkomisje do zbadania działalności podmiotów gospodarczych z udziałem Skarbu Państwa bądź instytucji państwowych oraz procesów prywatyzacyjnych. Zgodnie z art. 167 rS, ,komisje, na zasadach i w trybie określonych przez Prezydium Sejmu, moga przeprowadzać w wyznaczonym przez siebie składzie wizytacje oraz badania działalności poszczególnych zakładów oraz spółek z udziałem Skarbu Państwa, przedsiębiorstw i innych instytucji państwowych". Do realizacji tego celu komisja może powołać podkomisję nadzwyczajną. W badanym okresie od I do VII kadencji Sejmu utworzono dziewięć takich podkomisji ${ }^{50}$;

- podkomisje do zbadania i wyjaśnienia określonej sprawy. Są to podkomisje które budzą sporo kontrowersji. Charakter ich prac jest bardzo interesujący, jednak czasami wychodzą one poza swoje kompetencje, a nawet próbują odgrywać rolę quasi-komisji śledczych. Część spraw badanych przez takie podkomisje dotyczyła m.in. afer gospodarczych czy okoliczności wypadków lotniczych. Właściwie w każdym z tych przypadków pojawiały się głosy, że podkomisje nie są uprawnione do tego typu działań i wkraczają w kompetencje innych organów. Część tych zarzutów wydaje się uzasadniona w stosunku do podkomisji, które powołano po wejściu w życie Konstytucji RP z 2 kwietnia 1997 r., w której zawarto przepisy dotyczące komisji śledczej. Zgodnie z art. 111 ust. 1 ustawy zasadniczej, ,Sejm może powołać komisję śledczą do zbadania określonej sprawy". Tak więc to komisja śledcza ${ }^{51}$, a nie podkomisja powinna zajmować się badaniem takich spraw, jak afery gospodarcze czy odpowiedzialność organów państwowych w przypadku katastrof lotniczych ${ }^{52}$. Podkomisja nie jest właściwym miejscem do przesłuchiwania świadków, analizowania dowodów etc. W okresie od I do VII kadencji Sejmu powstało łącznie 12 podkomisji do zbadania i wyjaśnienia określonej sprawy ${ }^{53}$.

Ostatnim rodzajem podkomisji nadzwyczajnych, który można wyróżnić, to podkomisje problemowe. Są one bardzo zbliżone charakterem i zakresem działania do podkomisji stałych, co budzi pewne wątpliwości przedstawicieli doktryny. Można

podkomisje do kontroli realizacji ustaw: Podkomisję Nadzwyczajną do kontroli realizacji ustawy o najmie lokali mieszkalnych i dodatkach mieszkaniowych oraz Podkomisję Nadzwyczajną do kontroli funkcjonowania ustawy o własności lokali.

${ }^{50}$ M.in. w II kadencji Sejmu RP Komisja Przekształceń Własnościowych utworzyła Podkomisję Nadzwyczajną ds. zbadania przebiegu prywatyzacji Banku Śląskiego, a w VI kadencji Komisja Skarbu Państwa powołała Podkomisję Nadzwyczajną ds. prywatyzacji PZU S.A.

${ }^{51}$ Tryb działania komisji śledczej określa ustawa z dnia 21 stycznia 1999 r. o sejmowej komisji śledczej (Dz.U. 1999, nr 35, poz. 321, ze zm.), ponadto przepisy dotyczące funkcjonowania komisji śledczej znajdują się też w regulaminie Sejmu w rozdziale 11a.

52 Przed wejściem w życie Konstytucji RP z 1997 r. Sejm powoływał uchwałą komisje nadzwyczajne do zbadania określonej sprawy na podstawie art. 11 tzw. małej konstytucji z 1992 r.: „Sejm może powołać komisję do zbadania określonej sprawy z prawem przesłuchiwania w trybie Kodeksu postępowania karnego osób przez nią wezwanych".

${ }^{53}$ M.in. w IV kadencji Sejmu RP Komisja Gospodarki powołała Podkomisję Nadzwyczajną do zebrania informacji o kontrowersyjnych działaniach organów finansowych, ścigania i sprawiedliwości w stosunku do niektórych przedsiębiorców i menedżerów. Natomiast w VI kadencji Komisja Obrony Narodowej po serii wypadków lotniczych (w tym katastrofie pod Mirosławcem) powołała Podkomisję Nadzwyczajną ds. zbadania i kontroli procesu szkolenia personelu latającego Sił Zbrojnych RP. 
postawić tezę, że jest to właściwie próba obejścia wymogu związanego w koniecznością wyrażenia przez Prezydium Sejmu zgody na utworzenie podkomisji stałej ${ }^{54}$. Podkomisje problemowe nie różnią się bowiem od podkomisji stałych, jeśli chodzi o czas ich działania i często pracują permanentnie od chwili powołania do zakończenia kadencji. Ponadto zajmują się tematami, które leżą w kompetencjach komisji (zazwyczaj sformułowanych dość ogólnie). Łącznie w badanym okresie od I do VII kadencji powołano 26 tego typu podkomisji ${ }^{55}$.

Zdarza się też, że komisje sejmowe powołują najpierw podkomisje nadzwyczajne, a po uzyskaniu zgody Prezydium Sejmu zmieniają je swoją uchwałą w podkomisje stałe. Tak stało się m.in. w II kadencji Sejmu, kiedy Komisja Przekształceń Własnościowych utworzyła najpierw trzy podkomisje nadzwyczajne, a następnie przekształciła je w podkomisje stałe: Podkomisję Stałą ds. przekształceń własnościowych w sektorze paliwowo-energetycznym (jako podkomisja nadzwyczajna działała od 31 stycznia 1995 r. do 21 marca 1995 r.); Podkomisję Stałą ds. przekształceń własnościowych w sektorze bankowym (jako podkomisja nadzwyczajna działała od 6 września 1995 r. do 26 września 1995 r.) oraz Podkomisję Stałą ds. Narodowych Funduszy Inwestycyjnych (jako podkomisja nadzwyczajna działała od 21 marca 1996 r. do 5 listopada 1996 r.).

Bywają też przypadki próby racjonalizacji prac podkomisji stałych i ich łączenia, co nie zawsze przekładało się na efektywniejszą pracę podkomisji. W II kadencji Sejmu Komisja Spraw Zagranicznych powołała Podkomisję Stałą ds. instytucji międzynarodowych oraz Podkomisję Stałą ds. legislacyjnych. Obie podkomisje nie odbyły żadnego posiedzenia. Podjęto więc decyzję o połączeniu podkomisji i utworzeniu Podkomisji Stałej ds. legislacyjnych i instytucji międzynarodowych. Te działania nie na wiele się jednak zdały, ponieważ nowa połączona podkomisja również nie odbyła żadnego posiedzenia, mimo że istniała nieprzerwanie do zakończenia kadencji.

\section{UWAGI PODSUMOWUJĄCE}

Zakres regulacji prawnych dotyczących działalności podkomisji, unormowany w regulaminie Sejmu, jest bardzo skromy. Umożliwia to różną interpretację przepisów oraz powoduje, że w tych samych sytuacjach stosuje się zupełnie inne rozwiązania, na co wyraźnie wskazują wnioski z analizy działalności podkomisji, przedstawionej w niniejszym artykule. Stąd też postulaty dotyczące ujednolicenia przepisów dotyczących działalności podkomisji i ujęcia ich w jednym miejscu w regulaminie Sejmu. Z całą

${ }^{54}$ Dość często zdarza się bowiem, że komisja powołuje podkomisję nadzwyczajną do określonego problemu, w przypadku, gdy Prezydium Sejmu nie wyrazi zgody na utworzenie podkomisji stałej w tej samej sprawie.

${ }_{55}$ M.in. w I kadencji Sejmu RP Komisja Spraw Zagranicznych utworzyła Podkomisję Nadzwyczajna Nowy Ład Światowy a polska racja stanu; w II kadencji Komisja Polityki Społecznej powołała Podkomisję Nadzwyczajną ds. dzieci; w III kadencji Komisja Rodziny powołała Podkomisję Nadzwyczajną ds. grup psychomanipulacyjnych; w IV kadencji Komisja Rolnictwa i Rozwoju Wsi powołała Podkomisję Nadzwyczajną ds. biopaliw; w VII kadencji Komisja Obrony Narodowej powołała Podkomisję Nadzwyczajną ds. społecznych inicjatyw proobronnych. 
pewnością należy też wyeliminować luki prawne, które mogą doprowadzić do paraliżu prac podkomisji w przypadku rezygnacji przewodniczącego i braku konsensu co do tego, który z zastępców ma kierować pracą podkomisji. Wprowadzenie rozwiązania, że w takich okolicznościach to przewodniczący komisji zwołuje i przewodniczy posiedzeniu podkomisji oraz poddaje pod głosowanie wybór nowego przewodniczącego podkomisji, rozwiązałoby sprawę.

Wydaje się też, że skutecznym sposobem na ukrócenie praktyk wykorzystywanych do blokowania prac nad ustawami w podkomisji (jak np. ,zamrażarka”) mogłoby być wprowadzenie do regulaminu Sejmu przepisu dotyczącego możliwości zwoływania posiedzeń podkomisji na wniosek 1/3 ogólnej liczby jej członków (tak jak jest w przypadku komisji).

Na zakończenie rozważań należy podkreślić, że w latach dziewięćdziesiątych $\mathrm{XX}$ w. podkomisje sejmowe stanowiły pewien wyjątek, natomiast obecnie stały się regułą i trwałym elementem systemu parlamentarnego, co niestety ma też swoje negatywne konsekwencje. Nagminnie ustanawiane podkomisje — zwłaszcza stałe — nie zawsze mogą wykazać się merytorycznym dorobkiem, czasami nawet może się wydawać, że jedynym celem ich powołania jest wypłata dodatków, przewidzianych w regulaminie Sejmu dla przewodniczących podkomisji.

\section{BIBLIOGRAFIA}

ŹRÓDŁA

Ustawa z dnia 9 maja 1996 r. o wykonywaniu mandatu posła i senatora (Dz.U. z 2016 r. poz. 1510 , ze zm.).

Ustawa z dnia 7 lipca 2005 r. o działalności lobbingowej w procesie stanowienia prawa (Dz.U. z 2005 r. nr 169, poz. 1414, ze zm.).

Ustawa z dnia 21 stycznia 1999 r. o sejmowej komisji śledczej (Dz.U. z 1999 r. nr 35, poz. 321, ze zm.).

Uchwała z dnia 30 lipca 1992 r. Regulamin Sejmu Rzeczypospolitej Polskiej (M.P. z 1992 r. nr 26, poz. 185, ze zm.).

\section{PIŚMIENNICTWO}

Chybalski P., Sposób kierowania obradami komisji sejmowej oraz jej prezydium w sytuacji wakatu na stanowisku przewodniczacego komisji, [w:] Regulaminu Sejmu w opiniach Biura Analiz Sejmowych, t. II, red. W. Odrowąż-Sypniewski, Wydawnictwo Sejmowe, Warszawa 2010.

Chybalski P., Pojęcie ,osoby wykonujacej zawodowa działalność lobbingowa” w zwiazku $z$ art. 154 ust. 2 a i 2 d regulaminu Sejmu oraz osoby uprawnione do uczestnictwa w posiedzeniu podkomisji, [w:] Regulaminu Sejmu w opiniach Biura Analiz Sejmowych, t. II, red. W. Odrowąż-Sypniewski, Wydawnictwo Sejmowe, Warszawa 2010.

Czarny P., Naleziński B., Organy Sejmu Rzeczypospolitej Polskiej, Wydawnictwo Sejmowe, Warszawa 2002. 
Kamiński M., Status prawny klubów i kół parlamentarnych w Sejmie RP, Wydawnictwo Adam Marszałek, Toruń 2015.

Karolczak J.M, Uprawnienia przewodniczacego podkomisji statej, [w:] Regulaminu Sejmu w opiniach Biura Analiz Sejmowych, t. II, red. W. Odrowąż-Sypniewski, Wydawnictwo Sejmowe, Warszawa 2010.

Pajdała H., Komisje sejmowe status i funkcjonowanie, Wydawnictwo Sejmowe, Warszawa 2003.

Przejrzystość procesu stanowienia prawa Raport z realizacji projektu Spoleczny monitoring procesu stanowienia prawa, Fundacja im. Stefana Batorego, Warszawa 2008.

Radziewicz P., Status podkomisji w świetle regulaminu Sejmu i praktyki, „Przegląd Sejmowy” 2006, nr 4.

Stębelski M., Udzial gości w posiedzeniach podkomisji sejmowych (art. 154 ust. 3 w zwiazku $z$ art. 165 ust. 2 regulaminu Sejmu, [w:] Regulaminu Sejmu w opiniach Biura Analiz Sejmowych, t. II, red. W. Odrowąż-Sypniewski, Wydawnictwo Sejmowe, Warszawa 2010.

Zubik M., Organizacja wewnętrzna Sejmu Rzeczypospolitej Polskiej, Wydawnictwo Sejmowe, Warszawa 2003. 